\title{
Does endotracheal tube clamping during intubation of COVID-19 patients increase the risk of negative pressure pulmonary edema?
}

\author{
Mohsen Savaie, MD $\mathbb{D}$
}

Received: 13 September 2020/Revised: 17 September 2020/Accepted: 18 September 2020/Published online: 13 October 2020

(C) Canadian Anesthesiologists' Society 2020

To the Editor,

The recent letter in the Journal from Jacob et al. describes a technique for clamping an endotracheal tube (ETT) before connecting it to a ventilator circuit to attenuate the emission of aerosols during intubation of coronavirus disease (COVID-19) patients. ${ }^{1}$ They suggest using ETT clamping and unclamping during intubation, extubation, and suctioning procedures. ${ }^{1}$ Despite the protective effect of this method against exposure risk, it may potentially increase the risk of negative pressure pulmonary edema (NPPE) induced by the increased negative intrathoracic pressure due to inspiratory efforts against the obstructed (clamped) upper airway. ${ }^{2}$

In addition, respiratory effort with an obstructed airway may facilitate the aspiration of supraglottic contents into the trachea and may induce ventilator-associated pneumonia. $^{3}$

The development of NPPE can potentially worsen hypoxemia in COVID-19 patients and may put the patient at risk for hypoxic brain injury or cardiac arrest. ${ }^{4}$ It would seem that a safer alternative to ETT clamping devices would simply be to ensure deep sedation to attenuate patient airway reflexes (and coughing), as well as the use of recommended personal protective equipment and an adequately ventilated environment allowing for sufficient air exchanges to reduce aerosol transmission. ${ }^{5}$

Disclosures None.

M. Savaie, MD ( $₫)$.

Pain Research Center, Ahvaz Jundishapur University of Medical

Sciences, Ahvaz, Iran

e-mail: drsavaie@gmail.com
Funding statement None.

Editorial responsibility This submission was handled by Dr. Hilary P. Grocott, Editor-in-Chief, Canadian Journal of Anesthesia.

Editor's note The authors of the article: Can J Anesth 2020; 67: 1468-70, respectfully declined an invitation to submit a reply to the above letter.

\section{References}

1. Jacob M, Ruivo E, Portela I, et al. An innovative endotracheal tube clamp for use in COVID-19. Can J Anesth 2020; 67: 1468-70.

2. Bhattacharya M, Kallet RH, Ware LB, Matthay MA. Negativepressure pulmonary edema. Chest 2016; 150: 927-33.

3. Lerma FÁ, García MS, Lorente L, et al. Guidelines for the prevention of ventilator-associated pneumonia and their implementation (Spanish). The Spanish "Zero-VAP" bundle. Med Intensiva 2014; 38: 226-36.

4. Yao W, Wang T, Jiang B, et al. Emergency tracheal intubation in 202 patients with COVID-19 in Wuhan, China: lessons learnt and international expert recommendations. Br J Anaesth 2020. DOI: https://doi.org/10.1016/j.bja.2020.03.026.

5. Lockhart SL, Duggan LV, Wax RS, Saad S, Grocott HP. Personal protective equipment (PPE) for both anesthesiologists and other airway managers: principles and practice during the COVID-19 pandemic. Can J Anesth 2020; 67: 1005-15.

Publisher's Note Springer Nature remains neutral with regard to jurisdictional claims in published maps and institutional affiliations. 